\section{Analysis of Quantitative Traits and Estimation of Heritability in Early Generations of a Single Cross in Soybean (Glycine max (L.) Merrill)}

\author{
Vu Thi Thuy Hang and Vu Dinh Hoa \\ Faculty of Agronomy, Vietnam National University of Agriculture, Hanoi 131000, Vietnam
}

Received: March 6, 2017 Accepted: November 30, 2018

\section{Correspondence to} vtthang.nh@vnua.edu.vn

\section{ORCID}

Vu Thi Thuy Hang https://orcid.org/0000-0002-29518503

Vu Dinh Hoa https://orcid.org/0000-0002-38507064

\begin{abstract}
Genetic variability and heritability of quantitative traits, particularly of yield contributing traits, are of great importance in understanding phenotypic variation and the heritable portion of the variation when making selection choices. In the present study, the heritability for days to $50 \%$ flowering, days to maturity, plant height at maturity, total number of pods per plant, number-filled pods per plant, 100seed weight, and grain yield per plant were estimated by variance components from variance analysis of parents and $F_{2}$ and $F_{2: 3}$ progeny families derived from a single cross. Heritability estimates were high for days to $50 \%$ flowering and 100-seed weight, moderate for the number of pods per plant and number of filled pods per plant, and low for seed weight per plant. These results suggested that in the early segregating generations, direct selection for seed size, plant height, and a number of pods per plant might be more efficient than the direct selection for seed yield.
\end{abstract}

\section{Keywords}

Soybean (Glycine $\max$ (L.) Merrill), quantitative traits, heritability

\section{Introduction}

High seed yield is the primary aim of most soybean breeding programs. As in many crops, the extent of genetic improvement depends upon the genetic variability of the breeding population and the efficiency of the selection schemes. Soybean breeding techniques commonly exploit the genetic variability in segregating populations developed from crosses of two or more parents followed by individual plant selection. Variability in soybeans was used to improve agronomic performance traits such as yield, seed protein and oil content, and plant height, which enabled the selection of new germplasm (Fasoula et al., 2007 a, b, c). When utilized, variability can not only help improve yield and other agronomic performance traits, but also help improve plant tolerance 
to stresses and global changes in the environment. Thus, the presence and magnitude of genetic variability in a population is a prerequisite of a breeding program (St. Martin, 1985; Bhat et al., 2012).

The genetic improvement of quantitative characteristics, particularly seed yield, however, is often more difficult due to their polygenic control and environmental fluctuations, resulting in low heritability (Fehr, 1987; Burton, 1987; Coryell et al., 1999). As a result, selection for yield per se may not be rewarding unless other yield attributing traits are taken into consideration, especially if the individual components are highly heritable and genetically independent (Aditya et al., 2011). Thus, the estimation of different variance components, particularly the heritability, would provide information about the traits' variability. Furthermore, the heritability of a quantitative trait is very important to breeders in understanding the heritable portion of the total phenotypic variation, in choosing a selection method, and in determining the response to selection because it implies the extent of transmissibility of traits to the next generation. Further, heritability estimates are helpful in knowing the performance of parents in hybrids.

Heritability can be estimated by various means, i.e. parent-offspring regression (Warner, 1952; Falconer and MacKay, 1996) and/or by generation mean analysis (Warner, 1952; Mather and Jinks, 1982). Genetic analyses in soybean indicate that genetic variances and heritability estimates vary largely depending on the source populations/crosses and traits under investigation. Studies in segregating populations revealed that the heritability of plant seed weight was low while the heritabilities of days to maturity and plant height were high (Gomes et al., 2004; Hakim et al., 2014; Hakim and Suyamto, 2017).

The objectives of this study were to determine the magnitude of genetic variability and heritability of quantitative traits in $F_{2}$ and $\mathrm{F}_{2: 3}$ progeny families derived from a single soybean cross.

\section{Materials and Methods}

\section{Plant materials}

Soybean plants were selected from a working collection specifically created for plant height and plant seed yield made from a cross between two soybean accessions, VI045032 and GBVN004904, during the 2014 spring season. The accession VI045032 (purple flower) was introduced from AVRDC, and the accession GBVN004904 (white flower) was obtained from the Vietnam National Plant Resources Center.

\section{Cultural practices and trait measurements}

Forty-two $\mathrm{F}_{2}$ plants from the cross were grown in the spring of 2015. Twenty-seven $F_{2}$ plants randomly selected to establish $F_{2: 3}$ progeny families were planted in the 2015 summer-autumn season in double row plots with variable numbers of plants (18-30 plants) per family depending on seed availability. The two parents, VI045032 and GBVN004904, were intercalated in duplicate. Row and intra-row spacing was 40 and $15 \mathrm{~cm}$, respectively. Recommended cultural practices for growing soybean were applied. The $\mathrm{F}_{2}$ generation and $\mathrm{F}_{2: 3}$ progeny family evaluations were conducted at the Experimental Station of the Faculty of Agronomy, Vietnam National University of Agriculture. All plants in each family were observed and measured for estimating genetic parameters. The following traits were evaluated: days to $50 \%$ flowering, days to maturity (only for the $F_{2}$ generation), plant height at maturity, a total number of pods per plant, number of filled pods per plant, 100-seed weight, and grain yield per plant.

\section{Quantitative trait analysis and estimation of heritability}

Data were analyzed using Microsoft Excel (2010). The environmental variance, $\mathrm{V}_{\mathrm{E}}$, was estimated as the mean-variance among plants of the two parents $\left(\mathrm{V}_{\mathrm{P} 1}+\mathrm{V}_{\mathrm{P} 2}\right) / 2$, after checking for homogeneity of variance by Barlett's test. The broad-sense heritabilities of the traits in the $F_{2}$ generation were estimated using the following formula of Acquaah (2012): 


$$
H=\frac{V_{F 2-} V_{E}}{V_{F 2}}
$$

where $\mathrm{H}$ is the broad-sense heritability, $\mathrm{V}_{\mathrm{F} 2}$ is the total variance of the $\mathrm{F}_{2}$ generation, and $\mathrm{V}_{\mathrm{E}}$ is the environmental variance.

The trait variances for each of the $F_{2: 3}$ progeny families were computed using Microsoft Excel (2010) based on the following statistical model:

$$
Y_{i j}=\mu+f_{i}+e_{i j}
$$

where $Y_{i j}$ is an observation of the $j^{\text {th }}$ plant of the $i^{\text {th }} F_{2: 3}$ family, $\mu$ is the grand mean of the families or parents, $f_{i}$ is the genetic effect attributed to the $i^{\text {th }}$ family, and $e_{i j}$ is the effect among plants within families or parents.

The original data of the number of pods per plant and the number of filled pods per plant were transformed using square root transformations, $\sqrt{x}+0.5$, to adjust the data to the normal distribution curve (Costa et al., 2008). The variance analysis for the $F_{2: 3}$ progeny families and for each parent is presented in Table 1. Because of the different number of plants measured in each $\mathrm{F}_{2: 3}$ family and each parent, the value was adjusted as $\mathrm{k}_{\mathrm{f}}, \mathrm{k}_{1}$, and $\mathrm{k}_{2}$ representing the weighted averages of the number of plants measured for the families, parent $\mathrm{P}_{1}$, and parent $\mathrm{P}_{2}$, respectively, and were calculated as described by Costa et al. (2008).

$$
k_{f}=\frac{N-\left[\frac{1}{N} \sum n_{i}^{2}\right]}{f-1}
$$

$$
\begin{aligned}
& k_{1}=\frac{N_{1}-\left[\frac{1}{N_{1}} \sum n_{i}^{2}\right]}{p_{1}-1} \\
& k_{2}=\frac{N_{2}-\left[\frac{1}{2} \sum n_{i}^{2}\right]}{p_{2}-1}
\end{aligned}
$$

The variance components were estimated as follows:

The total phenotypic variance among $\mathrm{F}_{2: 3}$ progeny families

$$
\sigma_{A f}^{2}=\frac{M S_{A f}-M S_{W f}}{k_{f}}
$$

The environmental variance

$$
\begin{aligned}
& \sigma_{e}^{2}=\frac{1}{2}\left(\sigma_{e(\text { parent } 1)}^{2}+\sigma_{e(\text { parent } 2)}^{2}\right)= \\
& \frac{1}{2}\left(\frac{M S_{A p 1}-M S_{W p 1}}{k_{1}}+\frac{M S_{A p 2}-M S_{W p 2}}{k_{2}}\right)
\end{aligned}
$$

The genotypic variance

$$
\sigma_{G}^{2}=\sigma_{A f}^{2}-\sigma_{e}^{2}
$$

Broad sense heritability

$$
H=\frac{\sigma_{G}^{2}}{\sigma_{A f}^{2}}
$$

\section{Results}

\begin{tabular}{|c|c|c|c|}
\hline Source of variation & DF & Mean square & Expected mean square \\
\hline \multicolumn{4}{|l|}{ For $\mathrm{F}_{3}$ families } \\
\hline Among families & $f-1$ & $\mathrm{MS}_{\mathrm{Af}}$ & $\sigma^{2} W_{f}+k_{f} \sigma^{2} A f$ \\
\hline Within families & $N-f$ & $\mathrm{MS}_{\mathrm{wf}}$ & $\sigma^{2} w_{f}$ \\
\hline \multicolumn{4}{|l|}{ For parent $P_{1}$} \\
\hline Among plots & $p_{1}-1$ & $\mathrm{MS}_{\mathrm{Ap} 1}$ & $\sigma^{2} W_{p 1}+k_{1} \sigma_{A p 1}^{2}$ \\
\hline Within plots & $N_{1}-p_{1}$ & MS ${ }_{W p 1}$ & $\sigma^{2} w_{p 1}$ \\
\hline \multicolumn{4}{|l|}{ For parent $\mathrm{P}_{2}$} \\
\hline Among plots & $\mathrm{p}_{2}-1$ & $\mathrm{MS}_{\mathrm{Ap} 2}$ & $\sigma^{2} \mathrm{Wp}_{2}+\mathrm{k}_{1} \sigma_{\mathrm{Ap} 2}^{2}$ \\
\hline Within plots & $\mathrm{N}_{2}-\mathrm{p}_{2}$ & MS $w_{p 2}$ & $\sigma^{2} w_{p 2}$ \\
\hline
\end{tabular}

\section{Variability and heritability of the traits in the $F_{2}$ generation}

The range of the $F_{2}$ family means of the cross indicates the variability that might be expected in the progeny of a cross between two accessions. Among the traits studied, plant height at maturity, number of pods per plant, number of filled pods per plant, and seed weight

Table 1. Analysis of variance for each trait measured in the $F_{2: 3}$ progeny families

Note: $f=$ number of $F_{2: 3}$ progeny families, $p_{1}=$ number of parent 1 replications, $p_{2}=$ number of parent 2 replications, $N=$ total number of plants in the $F_{2: 3}$ progeny families observed, $N_{1}=$ total number of plants for parent $1, N_{2}=$ total number of plants for parent 2 . 
Analysis of quantitative traits and estimation of heritability in early generations of a single cross in soybean

Table 2. Estimates of range, mean, coefficient of variation, and of broad-sense heritability of yield contributing traits in the $F_{2}$ generation

\begin{tabular}{lcccc}
\hline \multicolumn{1}{c}{ Trait } & Range & Mean & $\begin{array}{c}\text { Coefficient of } \\
\text { variation (\%) }\end{array}$ & $\begin{array}{c}\text { Broad-sense } \\
\text { heritability }\end{array}$ \\
\hline Plant height at maturity (cm) & $12.5-53.5$ & 26.9 & 42.36 & 0.50 \\
Days to 50\% flowering & $45.0-58.0$ & 44.8 & 15.40 & 0.86 \\
Days to maturity & $94.0-113.0$ & 99.1 & 4.09 & 0.88 \\
Pod number per plant & $15.0-108.0$ & 43.1 & 48.87 & 0.20 \\
Filled pod number per plant & $15.0-106.0$ & 41.8 & 50.08 & 0.23 \\
100-seed weight (g) & $11.8-21.2$ & 17.4 & 11.84 & 0.79 \\
Seed weight per plant $(\mathrm{g})$ & $3.6-32.1$ & 13.8 & 47.77 & 0.23 \\
\hline
\end{tabular}

per plant showed the widest ranges and had the highest coefficients of variation (> 40\%); while days to $50 \%$ flowering, 100 -seed weight, and, particularly, days to maturity had lower variabilities (Table 2). These results indicated that plant height at maturity, number of pods, number of filled pods, and seed weight per plant were highly variable in the $\mathrm{F}_{2}$ generation.

Days to $50 \%$ flowering, days to maturity, and 100-seed weight had high heritability estimates of $0.86,0.88$, and 0.79 , respectively (Table 2). Plant height at maturity had moderate heritability, but the yield components (number of pods and number of filled pods per plant) and seed weight per plant had low heritability $(0.20$ 0.23 ). This indicated that days to $50 \%$ flowering, maturity, and seed size were highly heritable.

\section{Variability and heritability of the traits in the $F_{2: 3}$ progeny families}

The range of the $F_{2: 3}$ progeny families demonstrated the variability within each trait to some degree, but the means for plant height at maturity, days to $50 \%$ flowering and maturity, number of pods per plant, number-filled pods per plant, and 100-seed weight were very close to the mid-parent values, while the mean for seed weight per plant was not (Table 3 ). All the $F_{2: 3}$ progeny families from the present single cross had average plant seed yields exceeding both parents. Although no statistical test was conducted, one would expect that the difference is significant because of the fairly large number of observations involved in the means.

The heritability estimates were high for plant height at maturity, days to $50 \%$ flowering, a number of pods and number of filled pods per plant, and 100-seed weight (Table 4). These heritability estimates were comparable with those reported by Costa et al. (2008). In contrast, the seed weight per plant was of lowmoderate heritability (0.42) (Table 4). Although the heritabilities in this study might be slightly overestimated due to a rather limited number of $F_{2}$ and $F_{2: 3}$ progeny families, they indicated that most of the yield contributing traits resulting from a single cross are highly heritable and can be successfully selected for in an early segregating generation.

Table 3. Range and means of measured traits for the parents and $F_{2: 3-\text { progeny families }}$

\begin{tabular}{lccccccc}
\hline $\begin{array}{c}\text { Parent or } \\
\mathrm{F}_{2: 3} \text { family }\end{array}$ & $\begin{array}{c}\text { Plant height } \\
\text { at maturity } \\
(\mathrm{cm})\end{array}$ & $\begin{array}{c}\text { Days to } \\
50 \% \\
\text { flowering }\end{array}$ & $\begin{array}{c}\text { Days to } \\
\text { maturity }\end{array}$ & $\begin{array}{c}\text { Pod number } \\
\text { per plant }\end{array}$ & $\begin{array}{c}\text { Filled pod } \\
\text { number per } \\
\text { plant }\end{array}$ & $\begin{array}{c}\text { 100-seed } \\
\text { weight }(\mathrm{g})\end{array}$ & $\begin{array}{c}\text { Seed weight } \\
\text { per plant }(\mathrm{g})\end{array}$ \\
\hline VI045032 & 29.3 & 40.9 & 108 & 28.50 & 25.57 & 27.91 & 7.71 \\
G72 & 32.6 & 36.2 & 100 & 50.95 & 46.54 & 10.34 & 7.03 \\
F $_{2: 3}$ family range & $23.8-42.4$ & $36.2-41.2$ & $100-111$ & $32.3-71.4$ & $29.9-67.5$ & $14.5-22.3$ & $8.6-16.3$ \\
Mean & 32.50 & 38.45 & 104.22 & 46.97 & 43.29 & 17.31 & 10.50 \\
\hline
\end{tabular}


Table 4. Genotypic variance, environmental variance, and broad-sense heritabilities of measured traits in the $F_{2: 3}$ progeny families

\begin{tabular}{lccc}
\hline \multicolumn{1}{c}{ Trait } & $\mathrm{V}_{\mathrm{G}(\mathrm{F} 2: 3)}$ & $\mathrm{V}_{\mathrm{E}}$ & Broad-sense heritability $(\mathrm{H})$ \\
\hline Plant height at maturity & 33.244 & 6.332 & 0.84 \\
Days to 50\% flowering & 2.242 & 0.859 & 0.73 \\
Pod number per plant & 1.224 & 0.199 & 0.86 \\
Filled pod number per plant & 1.108 & 0.211 & 0.84 \\
100-seed weight & 136.168 & 16.641 & 0.89 \\
Seed weight per plant & 1.767 & 2.447 & 0.42 \\
\hline
\end{tabular}

\section{Discussion}

Estimates of heritability vary with each trait, population, and environment under study. Most studies have reported that seed yield was relatively low in heritability (Anand and Torrie, 1963; Toledo et al., 2000; Gomes et al., 2004; Costa et al., 2008; Bhat et al., 2012; Hakim and Suyamto, 2017; Kuswantoro et al., 2018), while plant height and days to maturity had moderate to high heritability (Gomes et al., 2004; Hakim et al., 2014; Hakim and Suyamto, 2017; Kuswantoro et al., 2018). For segregating populations following hybridization, heritability estimates depend on the parents used to make a cross, the handling of segregating generations during the stabilization phase, traits, and the generation per se. Anand and Torrie (1963), from studies using $\mathrm{F}_{3}$ and $\mathrm{F}_{4}$ generations from three soybean crosses, reported that heritability estimates for seed yield and number of pods per plant were relatively low whereas the estimates for seed weight were high. Toledo et al. (2000) studied F2, F3, F7, F8, F9, and F10 generations derived from six biparental crosses made from four cultivars and evaluated in 17 environments. Their results showed that the heritability for seed yield differed among cross combinations, years and, sowing dates (0.09-0.55), and the overall heritability was rather low (0.29). Gomes et al. (2004) also found that the heritabilities of days to maturity, plant height, and seed yield differed among crosses and generations, and, particularly, the general mean heritability estimate of all crosses for seed yield in the F6 generation (0.58) was higher than those in the F6:7 (0.21) generation.

Studies with 25 soybean genotypes (Malik et al., 2006) and with 91 soybean lines (Sulistyo et al., 2017) showed that the heritabilities of 100 -seed weight, days to $50 \%$ flowering, days to maturity, plant height, and grain yield per plant were high, and the authors concluded that these traits were governed by the additive type of gene action. Aditya et al. (2011) estimated the genetic variability of 31 soybean genotypes and found high heritability for days to $50 \%$ flowering, number of primary branches per plant, plant height, 100-seed weight, and seed yield per plant. Seed weight has also been shown to be rather high in heritability (Osekita and Olorufemi, 2014; Kuswantoro et al., 2018; Joshi et al., 2018). In the present study, heritability estimates for the number of pods and number of filled pods per plant in the $F_{2}$ generation differed from the $F_{2: 3}$ generations, of which the heritabilities were low in $F_{2}$ but rather high in $F_{2: 3}$. High heritabilities were estimated for days to $50 \%$ flowering, days to maturity, and 100-seed weight in both the $F_{2}$ and $F_{2: 3}$ generations, while heritability for plant height at maturity was moderate in $F_{2}$ and high in $F_{2: 3}$. Seed yield, however, was low in heritability in both generations. This is in contrast to that reported by Osekita and Olorufemi (2014) who found that the heritability for seed yield in an $\mathrm{F}_{3}$ population was extremely high (0.98). The high heritabilities of plant height at maturity, days to maturity, and 100-seed weight in both the $F_{2}$ and $F_{2: 3}$ generations in this study suggest that selection for these traits in early generations may be effective. In contrast, low heritability in seed yield and variable heritabilities of the yield components indicate that selection should be delayed to advanced generations among recombinant lines. 


\section{Conclusions}

High heritability is an indication of the presence of higher proportions of fixable additive variance in the population. The estimates of heritability when accompanied by high genetic advances are meaningful for breeders to design selection methods to be followed. Among the quantitative traits studied in the $F_{2}$ and $F_{2: 3}$ progeny families derived from a single cross of soybean in the present study, days to $50 \%$ flowering and 100 -seed weight had consistently high heritability. However, the plant height showed moderate heritability, and the heritability for a number of pods per plant and number of filled pods per plant varied with generation. The heritability of seed weight per plant was of low heritability in both the $F_{2}$ and $\mathrm{F}_{3}$ generations. This indicates that direct selection for seed yield in early generations would be less effective while selection for seed size, and probably plant height and number of pods per plant, might be more efficient. To make correct decisions for applying selections in segregating generations of soybeans derived from crosses, narrow-sense heritability estimations might be of necessity.

\section{Acknowledgements}

The authors wish to thank Vietnam National University of Agriculture (VNUA) for financial support through the VNUA Key Project on Soybean Improvement Program.

\section{References}

Acquaah J. (2012). Principles of genetics and plant breeding, $2^{\text {nd }}$ ed. Wiley Blackwell. pp. 64-94.

Aditya J. P., Bhartiya P. and Bhartiya A. (2011). Genetic variability, heritability and character association for yield and component characters in soybean (G. $\max$ (L.) Merrill). Journal of Central European Agriculture. Vol 12. pp. 27-34.

Anand S. C. and Torrie J. H. (1963). Heritability of yield and other traits and interrelationships among traits in the $\mathrm{F}_{3}$ and $\mathrm{F}_{4}$ generations of three soybean crosses. Crop Science. Vol 3 (6). pp. 508-511.

Bhat S., Basavaraja G. T. and Salimath P. M. (2012). Analysis of variability in segregating generation of soybean [Glycine max (L.) Merrill]. Karnataka Journal of Agricultural Sciences. Vol 25. pp. 176-178.
Burton J. W. (1987). Quantitative genetics: results relevant to soybean breeding. In: Wilcox J. R. (Ed.). Soybeans: Improvement, Production and Uses, $2^{\text {nd }}$ ed. Agronomy Monograph 16. ASA, CSSA and SSSA: Madison Wisconsin. pp. 211-247.

Coryell V. H., Jessenm H., Schupp J. M., Webb D. and Keim P. (1999). Allele-specific hybridisation markers for soybean. Theoretical and Applied Genetics. Vol 98. pp. 690-696.

Costa M. M., Di Mauro A. O., Uneda-Trevisoli S. H., Arriel N. H. C., Barbaro I. M., Silva G. D. D. and Munze F. R. S. (2008). Heritability estimation in early generations of two-ways crosses in soybean. Bragantia. Vol 67. pp. 101-108.

Falconer D. S. and Mackay T. F. C. (1996). Introduction to quantitative genetics, $4^{\text {th }}$ ed. Longman Group. London, UK.

Fasoula V. A., Boerma H. R., Yates J. L., Walker D. R., Finnerty S. L., Rowan G. B. and Wood E. D. (2007a). Registration of five soybean germplasm lines selected within the cultivar 'Benning' differing in seed and agronomic traits. Journal of Plant Registrations. Vol 1. pp. 156-157.

Fasoula V. A., Boerma H. R., Yates J. L., Walker D. R., Finnerty S. L., Rowan G. B. and Wood E. D. (2007b). Registration of seven soybean germplasm lines selected within the cultivar 'Cook' differing in seed and agronomic traits. Journal of Plant Registrations. Vol 1. pp. 158-159.

Fasoula V. A., Boerma H. R., Yates J. L., Walker D. R., Finnerty S. L., Rowan G. B. and Wood E. D. (2007c). Registration of six soybean germplasm lines selected within the cultivar 'Haskell' differing in seed and agronomic traits. Journal of Plant Registrations. Vol 1. pp. $160-161$.

Fehr W. R. (1987). Breeding methods for cultivar development. In: Wilcox J. R. (Ed). Soybeans: Improvements, Production and Uses. ASA, Wisconsin. pp. 249-294.

Gomes R. L. F., Vello N. A. and De Azevedo Filho J. A. (2004). Genetic analysis of $F_{6}$ and $F_{6: 7}$ soybean generations. Crop Breeding and Applied Biotechnology. Vol 4. pp. 35-42.

Hakim L., Suyamto E. P. and Paturohman E. (2014). Genetic variability, heritability and expected genetic advances of quantitative characters in $\mathrm{F}_{2}$ progenies of soybean crosses. Indonesian Journal of Agricultural Science. Vol 15. pp. 11-16.

Hakim L. and Suyamto E. P. (2017). Gene action and heritability estimates of quantitative characters among lines derived from varietal crosses of soybean genetic variability, heritability and expected genetic advances of quantitative characters in $\mathrm{F}_{2}$ progenies of soybean crosses. Indonesian Journal of Agricultural Science. Vol 18. pp. 25-32.

Joshi D., Pushpendra, Singh K. and Adhikari S. (2018). Study of genetic parameters in soybean germplasm 
based on yield and yield contributing traits. International Journal of Current Microbiology and Applied Sciences. Vol 7 (1). pp. 700-709.

Kuswantoro H., Artari R., Rahajeng W., Ginting E. and Supeno A. (2018). Genetic variability, heritability and correlations of some agronomical characters of soybean varieties. Biosaintfika. Vol 10 (1). pp. 9-15.

Mather K. and Jinks J. L. (1982). Biometrical genetics, $3^{\text {rd }}$ ed. Chapman and Hall, London.

Malik M. F. A., Qureshi A. S., Ashraf M. and Ghafoor A. (2006). Genetic variability of the main yiled related characters in soybean. International Journal of Agriculture and Biology. Vol 8. pp. 815-819.

Osekita O. S. and Olorunfemi O. (2014). Quantitative genetic variation, heritability and genetic advance in the segregating $\mathrm{F}_{3}$ populations in Soybean (Glycine $\max ($ L.) Merril. International Journal of Advanced
Research. Vol 2 (7). pp. 82-89.

St. Martin S. K. (1985). The application of quantitative genetics theory to plant breeding problems. In: Proceedings of the World Soybean Research Conference III, pp. 305-310.

Sulistyo A., Purwantoro A. and Sari K. P. (2017). Correlation, path analysis and heritability estimation for agronomic traits contributing to yield in soybean, International Symposium on Food and Agrobiodiversity (IFSA) 2017. doi:10.1088/17551315/102/1/012034, 6 pages.

Toledo J. F. F., Arias C. A. A., Olivera M. F., Triller C. and Miranda Z. F. S. (2000). Genetical and environmental analyses of yield in six two-way soybean crosses. Pesquisa Agropecuária Brasileira, Brasília. Vol 35 (9). pp. 1783-1796.

Warner J. N. (1952). A method for estimating heritability. Agronomy Journal. Vol 44. pp. 427-430. 